\title{
Article
}

Doi 10.5943/sif/2/1/10

Copyright $\odot$ Mushroom Research Foundation

\section{IMD: The first online database of documentation on Myxomycetes fungi from India}

\author{
Ranadive $\mathrm{KR}^{\mathbf{1}^{*}}$, Jagtap $\mathrm{NV}^{2}$ and Ranade $\mathrm{VD}^{3}$ \\ ${ }^{I}$ Dept. of Botany, Waghire College, Saswad, Taluka-Purandar, District-Pune, Maharashtra (India) \\ ${ }^{2}$ Dept. of Chemistry, Waghire College, Saswad, Taluka-Purandar, District-Pune, Maharashtra (India) \\ ${ }^{3}$ Retired. Head, Dept. of Botany, Abasaheb Garware College, Pune
}

Ranadive KR, Jagtap NV, Ranade VD 2017 - IMD: The first online database of documentation on Myxomycetes fungi from India. Studies in Fungi 2(1), 76-91, Doi 10.5943/sif/2/1/10

\begin{abstract}
The Indian Myxomycetes Database (IMD) is the first on-line database of information on Myxomycetes in India. The database contains 394 records from 11 families, 50 genera and 351 species, and can be accessed at www.fungifromindia.com. Every species from this much neglected group of fungi has been given a unique identity number that can be cited in publications where a new species is described. Every entry in this database has been linked with the globally recognized myco-database (www.mycobank.org). The IMD is part of an Indian initiative to promote international biodiversity documentation and form a global network of databases on biological information.
\end{abstract}

Key words - Indian Myxomycetes Database - MycoBank - Mycology

\section{Introduction}

Fungi and fungi like organisms are among the most important organisms in the world, not only because of their vital roles in ecosystem functioning but also because of their influence on humans and human-related activities. Fungi are essential to such crucial activities as decomposition, nutrient cycling, and nutrient transport and are indispensable for achieving sustainable development (Palm \& Chapela 1997). Although the diversity of fungi and fungus like organisms is daunting, we believe that variety, numbers, and importance mandate their inclusion in conservation dialogues and biodiversity projects. We also believe that they are tractable in a meaningful way. If the estimate is correct, then sites share enough species to make broad-scale inventory work possible yet harbors sufficient number of unique species to make valuable contributions to our understanding of fungi biodiversity and the ecological, evolutionary and genetic processes of these fungi and their associated organisms (Mueller et al. 2004). The ultimate aims of the present study were to study the occurrence and distribution of Myxomycetes from India and to give easy access for the information of Indian Myxomycetes to researchers and the students all over the world.

The present work has tremendous mycological significance and it will update the knowledge of Myxomycetes of India. This is the first Indian database on a much neglected group of fungi. The user friendly database will inspire the students as well as researchers to study the Myxomycetes taxonomy from India. Such type of database gives the information in very short period which will help researchers to save their energy and time for further research. 
Myxomycetes are plant-like in their manner of reproduction but resemble animals in the characteristics of their assimilative phase. The organism exhibits two alternating phases in its life cycle, the assimilative phase and the sporulating phase. The former consists of a free-living, acellular, mobile mass of protoplasm i.e., the plasmodium. The plasmodium absorbs nutrients from the surroundings and also engulfs solid particles including bacterial and fungal spores. The sporulating phase (sporocarp) bears spores externally on, or inside, a spore case. The spore case consists of an outer, generally persistent peridium, which envelops a free thread-like netted structure, the capilitium, which aids in spore dispersal. Myxomycetes are a cosmopolitan group of organisms that can be found in a variety of habitats including well-manicured lawns and flower beds, and damp places, especially on old wood or other plant material undergoing decomposition. Slime molds are also common on dung and a few species may be restricted to this substratum. Another more recently recognized, specialized niche is dead branches attached to living trees.

The important taxonomic treatises available on slime moulds include Lodhi (1934), Farr (1962), Martin \& Alexopoulos (1969), Alexopoulos (1963, 1967 \& 1969), Thind (1977), Lakhanpal \& Mukherji (1981). Several workers also reported Myxomycetes from different parts of India, which were published under the banner of Fungi of India. Martin GW (1932), Martin et al. (1957), Uppal BN et al. (1935), Mundkur BB (1938), Patel MK et al. (1948), Ramakrishnan \& Subramanian (1952), Subramaniam \& Ramakrishnan K (1956), Roy (1948), Vasudeva (1962), Mathur (1964), Subramaniam \& Tyagi (1964), Tilak \& Rao (1968), Rangaswamy et al. (1970), Kamat et al. (1971), Kowalski \& Lakhanpal (1973), Mukherji \& Juneja (1975), Sarabhoy et al. (1975, Sekhon (1976), Sekhon (1978), Sekhon (1979a,b), Bilgrami et al. (1979), Mishra \& Ranade (1979), Sood \& Lakhanpal (1980), Sarabhoy et al. (1980), Sarabhoy et al. (1986), Hosagoudar et al. (1996), Jagtap \& Singh (2002), Jamaluddin et al. (2004). Dr. Wight was perhaps the first person to collect a slime mould, Physarum cinereum (Batsch.) Pers., from Madras (Chennai), India on grass leaves in 1830.

Bruhl \& Gupta (1927), published the second paper on Indian Myxomycetes describing 16 species from West Bengal. Butler \& Bisby (1931, 1960), compiled a list of Indian Fungi and remarked, "The Myxomycetes have not been studied in India but many of these widely-distributed organisms occur there". They did not include any representative of this group in their compilation. However, Lister (1924, 1925), had already mentioned (under habit only) the occurrence of 18 species in different parts of India. Lodhi (1934), published a monograph of Indian slime moulds describing and illustrating 43 species. The period between 1952-1976 can be considered the Golden Period for the studies of Myxomycetes in India. Around 1952 interest was revived in this field. Dr. K.S. Thind in North India, and Dr. V. Agnihothurudu in South India, started work on Indian Myxomycetes almost simultaneously. Thind and other workers in a series of 24 research papers have described about 175 species from the North Western and Eastern Himalayas and the Punjab Plains. Thind \& Rehill (1957), Thind \& Sehgal (1960, 1964), Thind \& Manocha (1963), Thind \& Khara (1969). Their contributions include 19 new species and two new varieties. Agnihothrudu and his collaborators (Agnihothrudu 1954a, b, 1955 \&1956a, b c; Agnihothrudu \& Chinnappa 1966 \& 1969), (Indira 1968a \& b, 1975), have described 78 species from South India, including one new species.

Agnihothrudu (1952-1968), in a series of four papers described 56 species including two new species from North-East India. Ghosh \& Datta (1962 a, b, c \& 1963), from Orissa, Pathak \& Ghosh (1962), from Uttar Pradesh, Kar (1964), from Calcutta, Singh \& Pushpavathy (1965 \&1966), Singh et al. (1979) from Delhi, Patwardhan \& Joshi (1975), Patil \& Ranade (1975), Ranade \& Mishra (1977), Ranade (1978), Chavan \& Kulkarni (1974), Thite (1975) from Maharashtra, Dhillon (1976, 1977a \& b), and Dhillon et al. (1978), recorded more species of Myxomycetes from their respective places. In 1977, Prof. Thind published "Myxomycetes of India" describing and illustrating 182 species recorded up to 1973. Lakahanpal began work on Myxomycetes of Kulu and Simla in 1966 (Lakhanpal 1966, 1978), later extending the work to other parts of Himachal Pradesh. From 1965 to 1978 he collected about one thousand specimens, including about 75 from Delhi (1969-1975). In his doctoral thesis, Lakahanpal described and illustrated 156 species. 
In this work he recorded 7 genera and 43 species for the first time from India and described 22 species new to science. He also reported 50 species (and one variety) from Delhi, and 83 species from Himachal Pradesh for the first time. He also amended the diagnosis of Metatrichia vesparium and Physarum laevisporum and resolved the controversy regarding the delimitation of the species of Lycogala on the basis of the ontogeny of their corticals scales. Lakhanpal (Lakhanpal \& Mukherji 1981), in a series of 19 papers entitled "Taxonomic studies on Indian Myxomycetes - IXVII" and "Experimental studies on Indian Myxomycetes - I and II" described and illustrated more than 62 species from Himachal Pradesh and Delhi and have recorded their observations on the life cycle and sporangial development of some important species such as Licea scyphoides Keller \& Brookes and Clastoderma debaryanum Blytt. They also conducted cultural studies on some species of Didymium i.e., Didymium muscorum Lakhanpal \& Mukherji, D. karstenii Nann.Bremk., D. intermedium Schroet. and Didymium squamulosum (Alb. \& Schwein.) Fr. \& Palmquist. Earlier, Thind \& Lakhanpal (1968a, b, c) described 16 species and Lakhanpal (1971-1973), 56 species from Himachal Pradesh, including some already described by him with Prof. Thind. Kowalski \& Lakhanpal (1973) and Lakhanpal (1972 a \& b), described one genus and ten species from Delhi. Lakhanpal (1972 a \& b) recorded five species from Nainital in Uttar Pradesh. Many species have been collected from natural habitats since 1976 and some more interesting forms have been obtained, in moist chambers, from the bark of living trees. The work after 1976 has seen contributions from Nannenga-Bremekamp et al. (1958a, b \& 1967), Farr (1962), Singh \& Pushpavathy (1965, 1966 \& 1979), Tandon et al. (1964), Patil \& Mishra (1977), Ranade \& Mishra (1977), Mishra \& Ranade (1979), Nanir (1979), Bhide et al. (1987), Nanir et al. (1987), Rokade \& Nanir (1993), Kaur \& Mukerji (1996), Wrigley and Lado (2005), Tembhurne \& Nanir (2011), Ranade et al.( 2012). Distribution of Myxomycetes in India: Temperature, humidity, rainfall, and topography are the main factors that determine the distribution of Myxomycetes. It is suggested that Myxomycetes attack wood after it has been partially degraded by Basidiomycetes, but their role in the decay of conifer wood may be understated. The present study provides a checklist containing 373 species of Mxyomycetes, 17 varieties and 4 forms within 50 genera, 11 families and 6 orders (Table 1). Liceales is the dominant order with 3 families. Stemonitaceae is the dominant family with 12 genera and Physarum is the dominant genus with up to 76 species in India. Worldwide, these 50 genera recorded in India are represented by 2344 species, 523 varieties, 4 subspecies and 58 forms (Table 2). Various classification systems of Kingdom Fungi have been proposed by mycologists, among which is the recent classification system given by Alexopoulos et al. (1996). However, the present study has taken into consideration the Ainsworth system of classification of Fungi (Ainsworth et al. 1973). For classification of Myxomycetes (also called Acellular slime moulds or True slime moulds), a system proposed by Martin (1932) is used.

\section{Materials \& Methods}

\section{Digitization work - Database preparation (Indian Myxomycetes Database i.e. IMD) Card preparation}

More than 400 reference cards of size $17.5 \times 12.5 \mathrm{~cm}$ were prepared from extensively surveyed Indian literature including reference books, research papers and explanatory notes. The latest nomenclatural change has been added on the card by different coloured ink. The basic reference is quoted at the right-hand corner of the ruled card. The important references of the same species are added on the back side of the reference card. The information on the card is kept in similar format for all the cards as follows.

\section{Digitization}

India has been the cradle of knowledge for thousands of years. Today there is a felt need to preserve and propagate indigenous knowledge and culture along with the acceptance of universal knowledge through globalization in this age of technological developments. The IT oriented environment has brought in opportunities of a revolutionary nature in archiving and accessing 
knowledge in the digitized form which were known to exist in conventional libraries mainly in the print form. India has undertaken many initiatives to digitize its documented knowledge base and set up digital libraries for better access to its diverse client. India needs well planned and policy based digitization efforts to be effective in the present situation. Digitization has become the buzz word in every field of information generation, processing, preservation and access. There are many prestigious nationally and internationally funded activities which are being undertaken simultaneously by many institutions and agencies. Indian digitization programmes are in their initial stages and it is now considered to be the most favored activity in the field of information generation, processing, dissemination and preservation. In this situation of hype, it is hardly understood that applying digital technologies will be a complex process of experimentation with gains and losses, triumphs and failures (Nagarkar 2000, Dasgupta 2005).

Digital technology has raised the hopes and expectations of people to face the challenges of not only bridging the gap between the information rich and the information poor in the country, but also uplifting the level of development in all its different facets. Major responsibility now rests on the decision makers, technological experts, librarians, educationists, social workers, legal experts, publishing industry as well as the local institutions to play their respective roles in bringing digital information in need based comprehensible form and language to the diverse clientele of the country. No agency can really work in isolation to reach the expected goal in the right manner. Therefore, coordinating agencies may have to be established on a distributed regional basis to understand local requirements and thereby assist policy planners in preparing proper guidelines for useful and sustainable digitization programmes.

The available technical infrastructure and the networks in existence may now be utilized while initiatives for more sophisticated technology becomes successful in creating proper infrastructure to deal with the multi-lingual and multi-sectoral information required for the vast majority of Indians. Just as the audiovisual media such as TV and radio have reached every corner of India, digital technology will one day become a household facility in distant parts of the country. Since Indian decision makers have now understood that Information is power and information based decision making has become the order of the day, the Government of India and other agencies are taking necessary steps to improve the telecommunication and other technical facilities to make IT based Information access a reality in the true sense so that there can be substantial improvement in the quality of life of every Indian (Dasgupta 2005).

\section{Card}

\begin{tabular}{|l|}
\hline Short form of the reference at right hand side top corner \\
Recent name of the species \\
Old name of the species \\
Family \\
Host \\
Locality \\
Distribution \\
Reference sited \\
\hline
\end{tabular}

\section{Data Feeding in Excel}

The data on the above said cards is feed in different columns sequence wise as that of the card information so that the uniform system is developed in the database. MS Office 2007 has been used for creating the MS Excel sheets. The advantage of the excel sheet data was that we could import the same data in any usable format, which was not possible in other forms so easily. More than 400 entries of the records have been done from all over India very keenly. 


\section{Database Building}

In this database the software's which are used as follows:

DBMS

Serverside script

Server

Javascript library
: MySQL Server 5.0

: PHP 5.2.9

: Apache 2.2

: Scriptaculosus

Being reference data it is not complex in terms of relationships between the files. But the complexity is present in terms of repeating phrases/words and different words with same/similar meaning. The primary key for the record table is defined by the collection of three columns viz. genus, species and original reference. The original reference field had to be added in the primary key since there can be repeating genus-species combination obtained from different sources of data. Uid is the unique identification number for each record. The columns in the database are as follows:

\section{Software}

Between the physical database, itself (i.e. the data as actually stored) and the users of the system is a layer of software, usually called the database management system or DBMS. DBMS provides a view of the databases that is elevated somewhat above the hardware level and supports user operations that are expressed in terms of that higher-level view. In this database, the software's which are used are as follows:

\section{Description of All Pages of Database}

The website contains the pages as follows Home page, General search (Simple search), Advanced Search, Output of the search, Browse, Card viewer, Card, References page, Contact page, Site Map, Help Page, Publications and Data entry page.

\section{Home page}

It contains introductory information and links to other pages. Data statistics given on the front page will change automatically as per the updates in the data records (Fig. 1).

\section{General search (Simple Search) Page (Fig. 2)}

It contains a text input field where user can type keywords to be searched. There is also a dropdown box for selecting the operation (AND/OR). A button is added to the page which is used to initiate the querying process. When this search button is pressed on 'onclick' event is fired and subroutine is called. This subroutine (written in java script) takes key words and operator from corresponding fields of the pages and sends it to the serverside script that accesses the database (here it is simple search.php). This script works in backend to search for the data. If the data matching to the query is found, the script generates a tabular output in html format and returns it to the client. Being in the "html format", the data can then be viewed in browser as the html page that contains the search results.

\section{Advanced Search Page (Fig. 3)}

This page contains three input fields as follows

a. Dropdown box - For selecting database field to be searched.

b. Text input field - For Keywords, dropdown box for logical Operate.

c. Row join operator - For joining multiple searches.

The set of these three basic input fields mentioned above form a single search. More than one searches can be performed in one go by adding such sets of three field s and joining them by 'row join operator'. For this add and remove buttons are given (Fig. 2). 


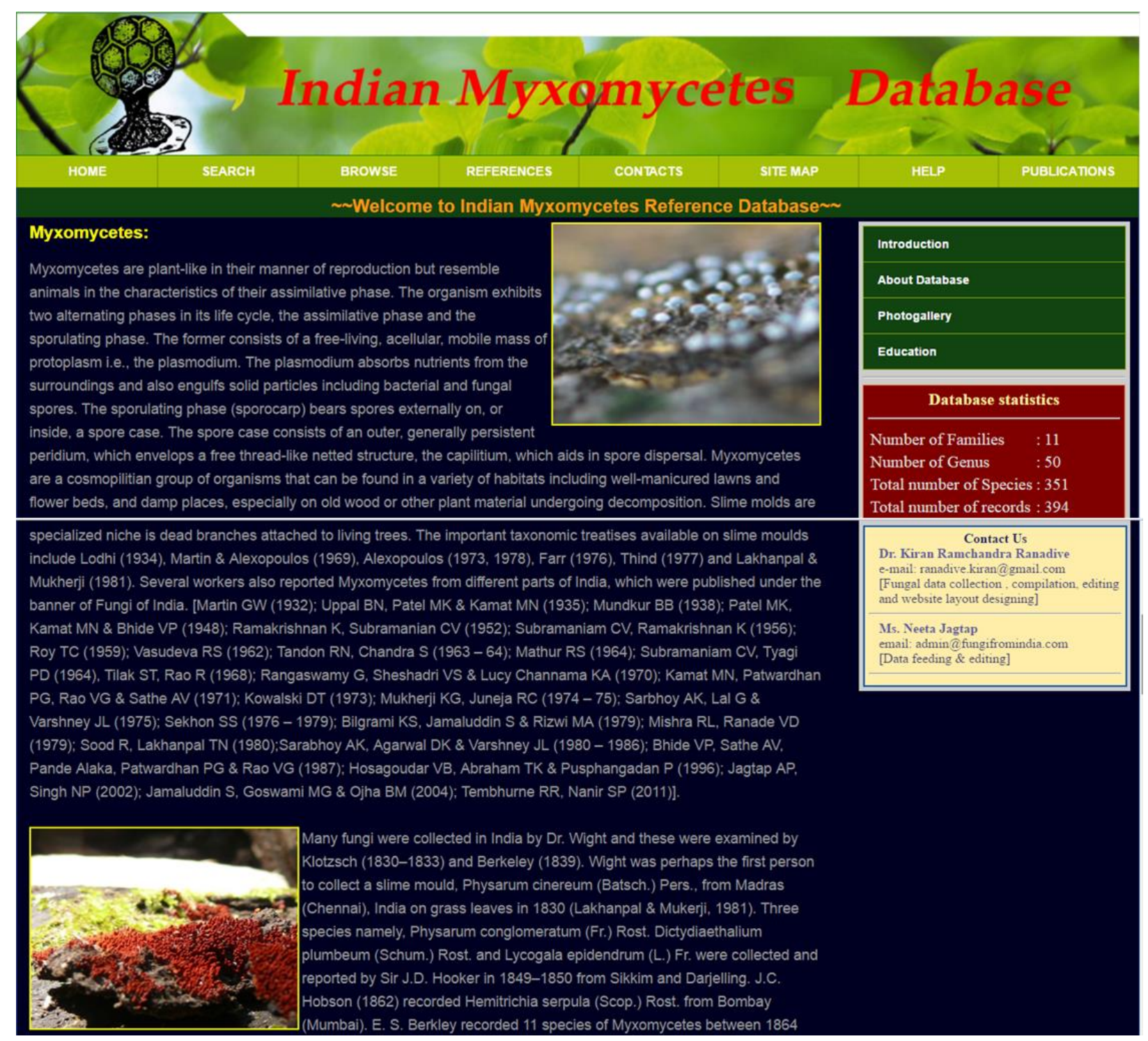

Fig.1 - Indian Myxomycetes Database Home page

\section{Output of the Search}

Both simpleSearch.php and advSearch.php generate output in same format. The searched records are presented in a tabular format with serial number, IMD-ID number genus name, species name and family name as the columns. The output generated by this script is in a card format and is not presented to the user as different page but is dynamically embedded in the existing search results page. This achieves the purpose of both user friendliness and the minimum amount of data transfer. The embedded page is formatted in such a way that the user feels as if looking the hardcopy of the card. The card can be closed using the provided 'close' button and other cards can be reviewed in the same page without querying the database again and again (Fig. 4).

\section{Browse page (Fig. 4)}

Browse: Family

Browse: species specific query

Output of browse queries is same as that for search queries. 


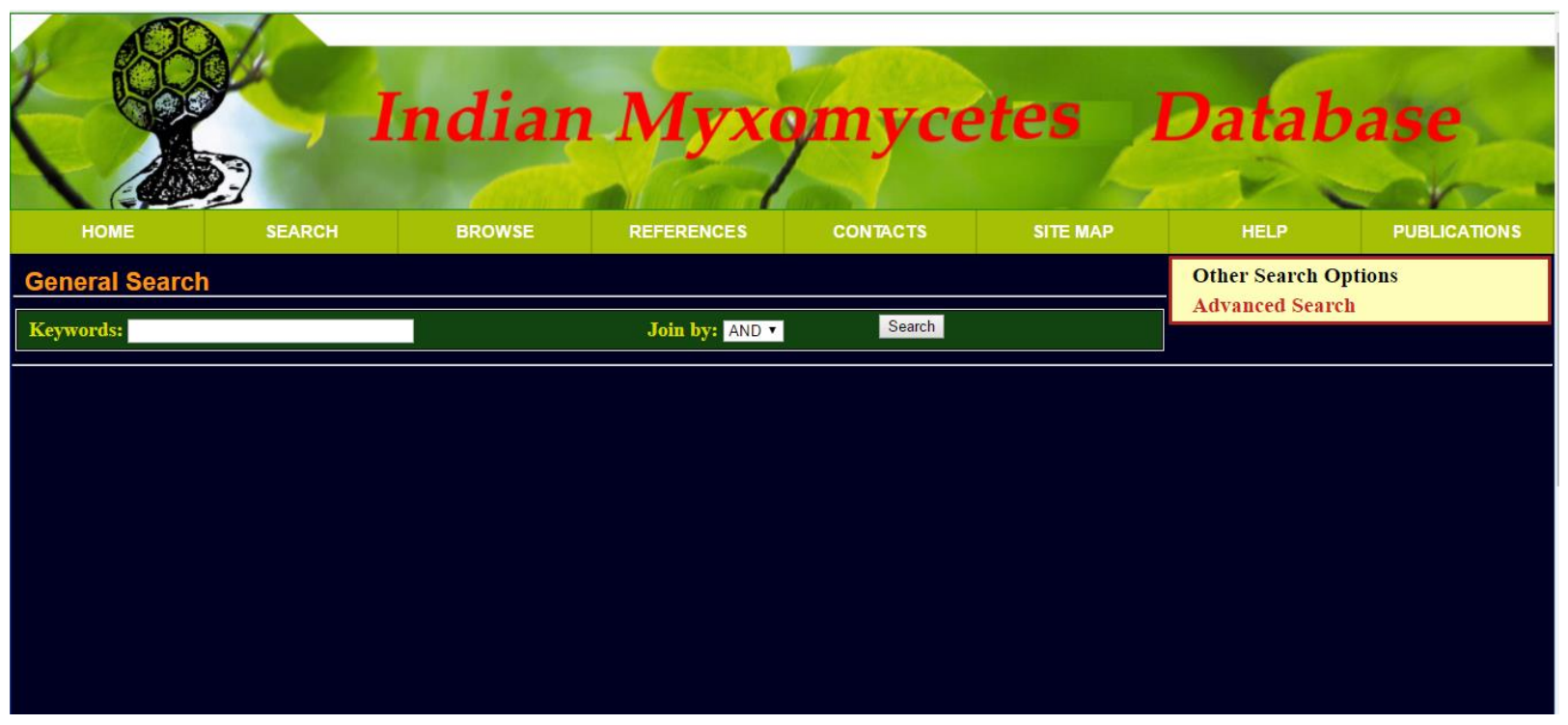

Fig. 2 - Database General Search (Simple Search) and Advanced Search page

\section{Card Viewer (Fig. 6)}

This page will display the card as well as the background showing glimpses of the result of the query put by the user/visitor. This function will help the user/visitor to get back to the species in which lies client's second interest.

\section{Card (Fig. 7)}

The card is the source of all basic information like

IMD Number (The Unique Indian Myxomycetes Database Number)

Name of the species

UID (Unique ID number given to every Record from The Database)

Family Name

Host

Locality

Geographical Distribution

Original Reference (From where the data of the is taken)

Research Work Reference (Any other research reference to be added)

\section{References Page (Fig. 8)}

This page includes more than 19 major references used for this Database. Reference books, Ph.D. Thesis of the related subjects are given sequentially.

\section{Contacts Page (Fig. 9)}

This page shows the photographs and bio data of the authors Database for any further queries about the Database.

\section{Site Map (Fig. 10)}

In this page the short cut links are given for every major part of topics of the Database which occurs on the task bar of the Database. It is very much easier for every visitor of this Database. 


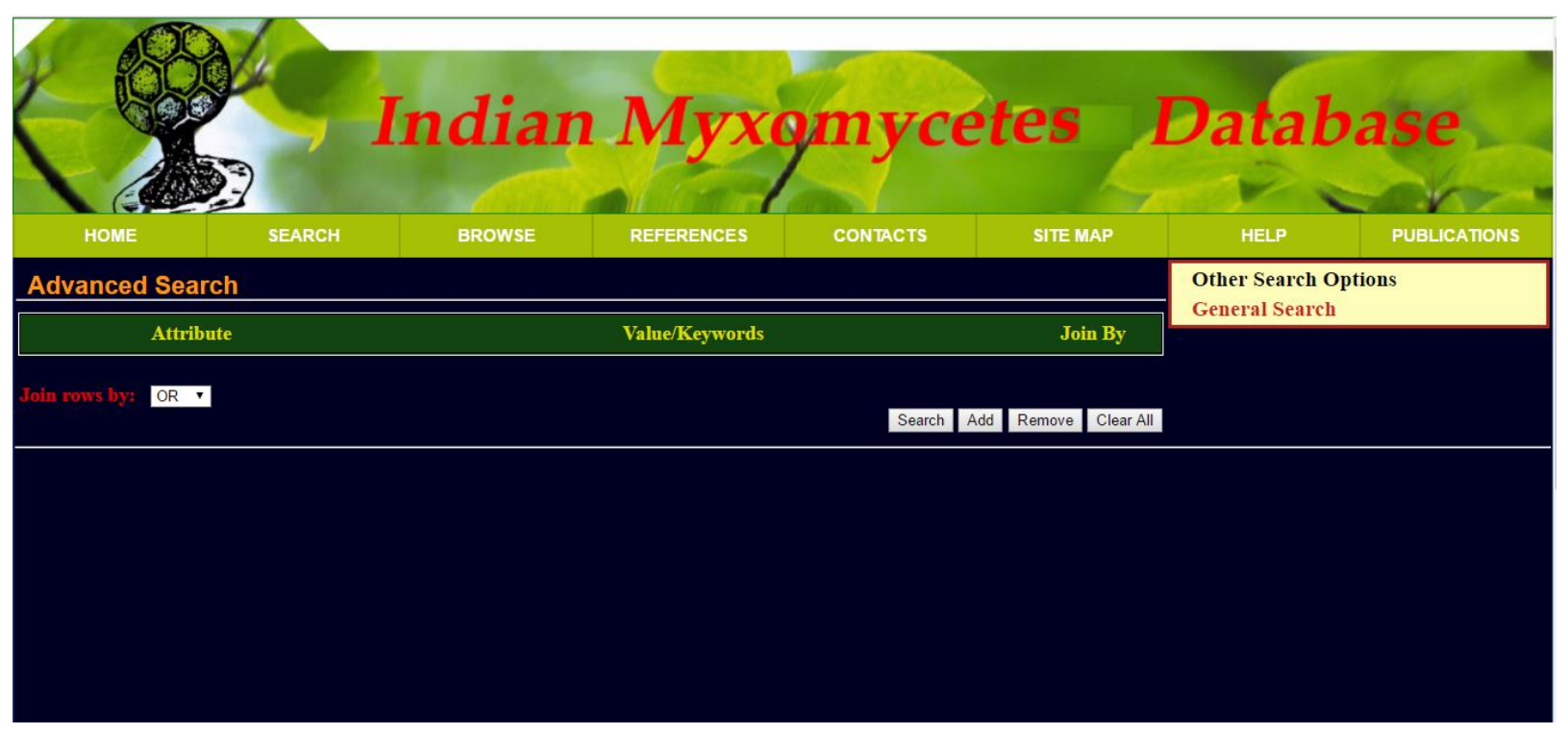

Fig. 3 - Database Advanced Search page

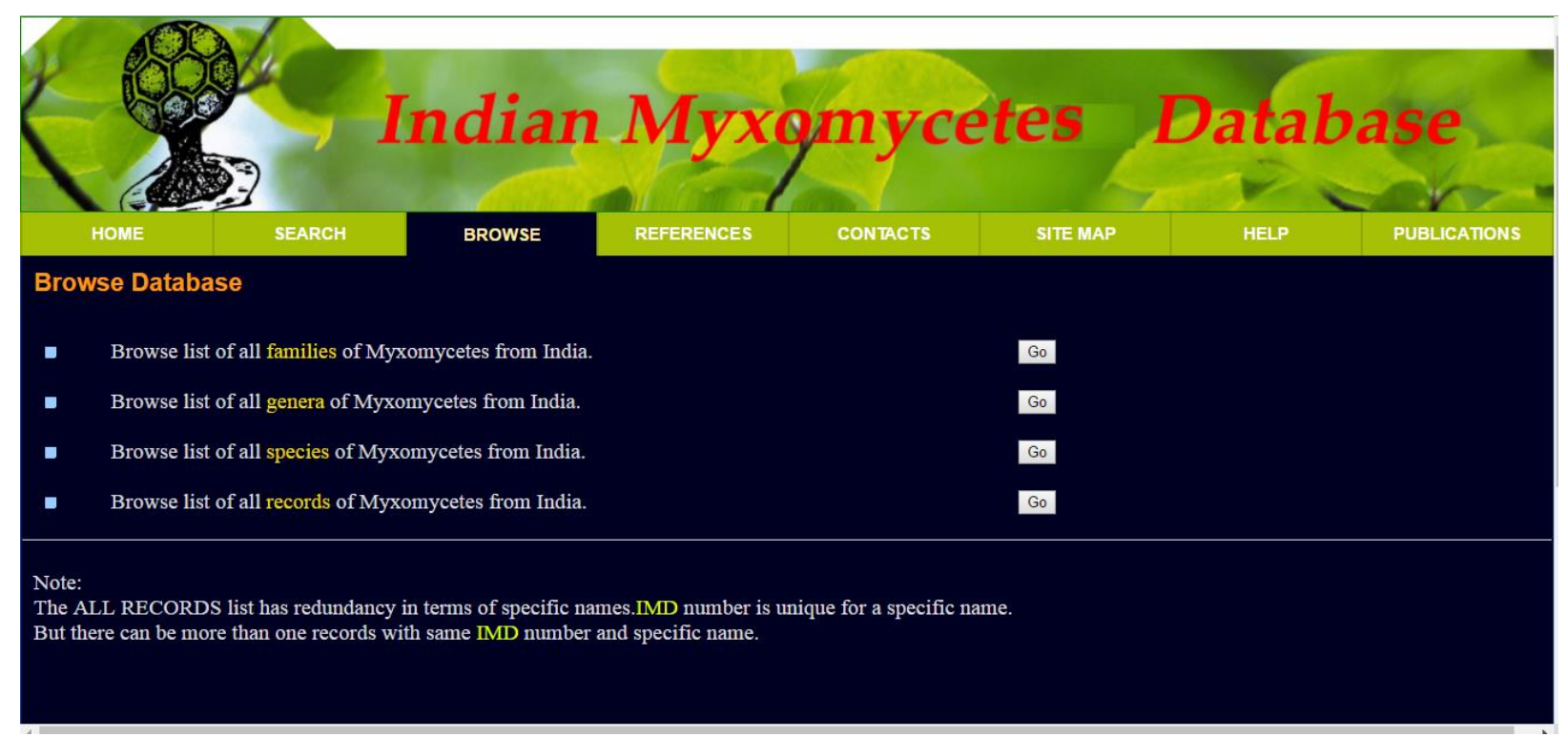

Fig. 4 - Database Browse page

Help Page (Fig. 11)

This page is really the encouraging page for every visitor of the Database because it gives every help regarding (How to use the database?) its use. The page is having the screen shots of all the pages which will help the student as well as researchers to solve their difficulties regarding the use of the Database.

\section{Publications}

This is the section is under progress which will be containing the publications done by all authors from India and abroad.

\section{Results}

The present work has contributed for the first time in India about the Myxomycetes reference database. In this study more than 400 reference cards were prepared in a standard way. The database shows total 394 records in which total 351 species were recorded from 11 families and 50 
genera of Myxomycetes from all over India. This IMD has been launched online on www.fungifromindia.com. Every species of this database has been linked to the www.mycobank.org.

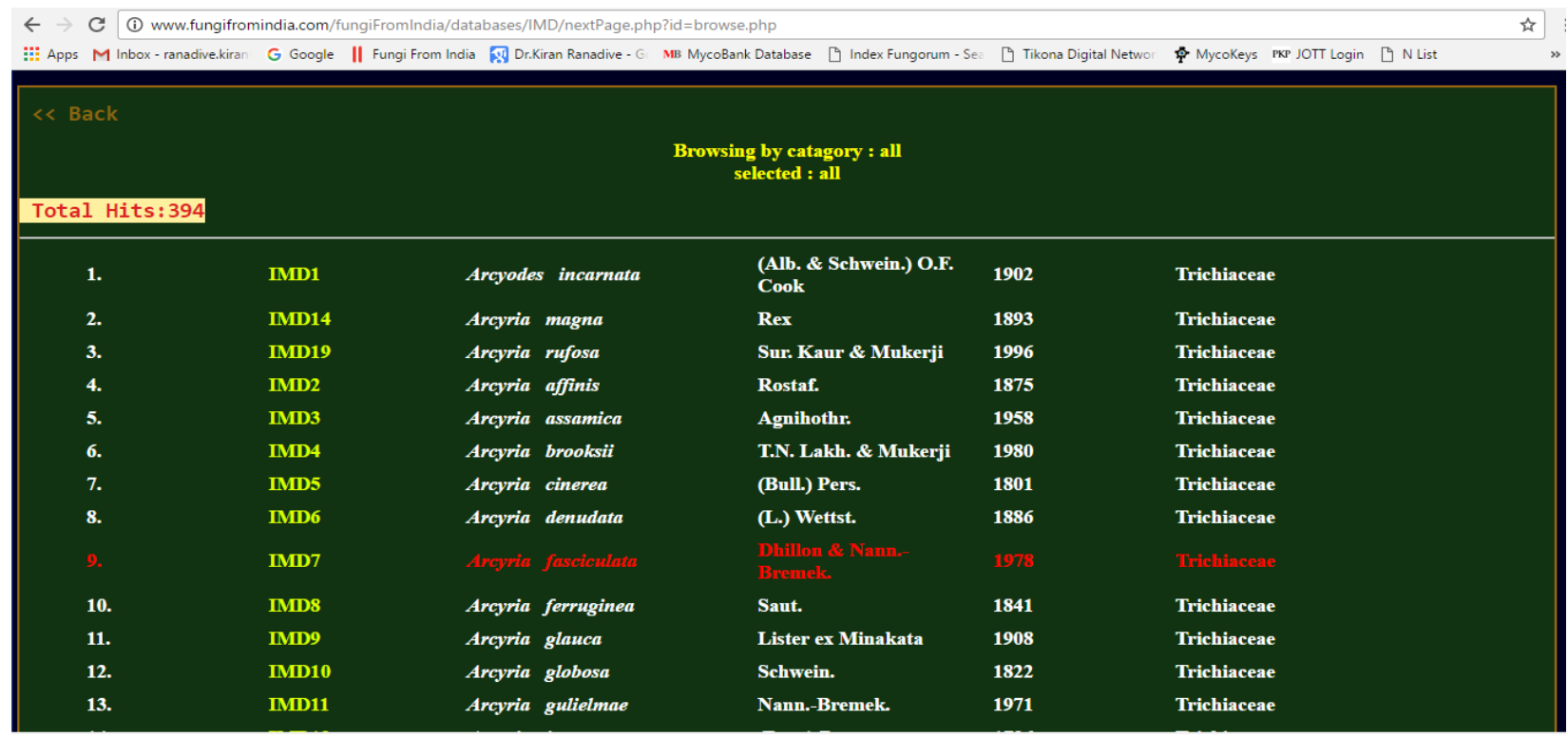

Fig. 5 - Database Search page result

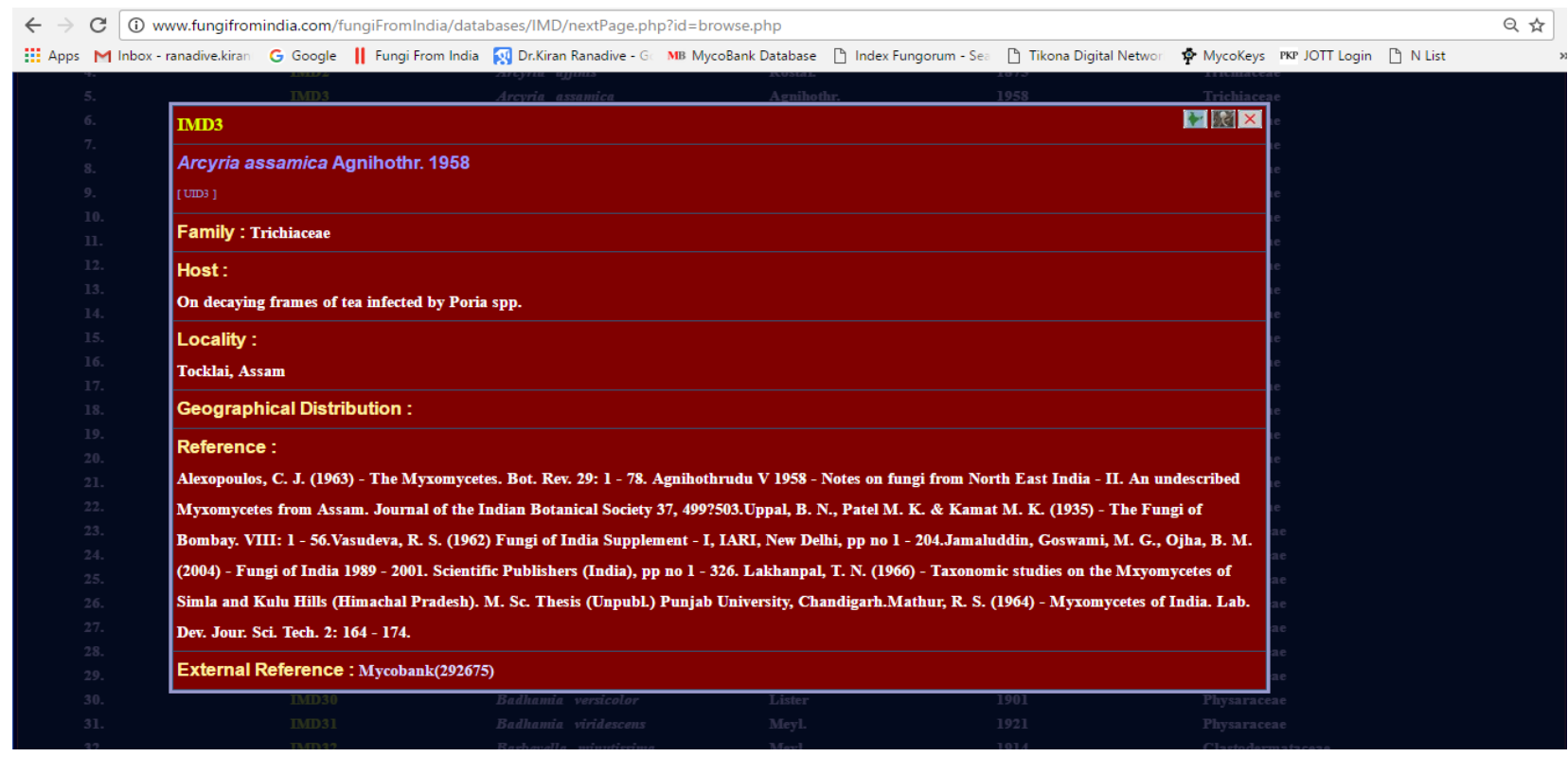

Fig. 6 - Database Card viewer

\section{Discussion}

The literature on fungi is scattered in journals, not easily accessible to the Indian students. The unavailability of the related literature may develop the disliking of the subject, so in such case our IMD-Reference Database (The database giving all Myxomycetes references from India on a single click, i.e. on IMD- Indian Myxomycetes Database) will minimize the efforts and time for the survey of literature. This is the first Indian effort to do such contribution in the history of Indian Mycology and just made available free of cost for all researchers from world. This database will help to the new comers in the field and it is available free of cost online. This database work has been completely funded by the author himself only. This is expected to serve as an initial step towards better understanding of the Myxomycetes from any locality of India. 


\section{IMD3}

Arcyria assamica Agnihothr. 1958

[UTB]

Family : Trichiaceae

Host:

On decaying frames of tea infected by Poria spp.

Locality :

Tocklai, Assam

Geographical Distribution :

Reference :

Alexopoulos, C. J. (1963) - The Myxomycetes. Bot. Rev. 29: 1 - 78. Agnihothrudu V 1958 - Notes on fungi from North East India - II. An undescribed Myxomycetes from Assam. Journal of the Indian Botanical Society 37, 4992503.Uppal, B. N., Patel M. K. \& Kamat M. K. (1935) - The Fungi of Bombay. VIII: 1 - 56.Vasudeva, R. S. (1962) Fungi of India Supplement - I, IARI, New Delhi, pp no 1 - 204.Jamaluddin, Goswami, M. G., Ojha, B. M. (2004) - Fungi of India 1989 - 2001. Scientific Publishers (India), pp no 1 - 326. Lakhanpal, T. N. (1960) - Taxonomic studies on the Mryomycetes of Simla and Kulu Hills (Himachal Pradesh). M. Sc. Thesis (Unpubl) Punjab University, Chandigarh.Mathur, R. S. (1964) - Myxomycetes of India. Lab. Dev. Jour. Sci. Tech. 2: 164 - 174.

External Reference : Mycobank(292675)

\section{Fig. 7 - Card}

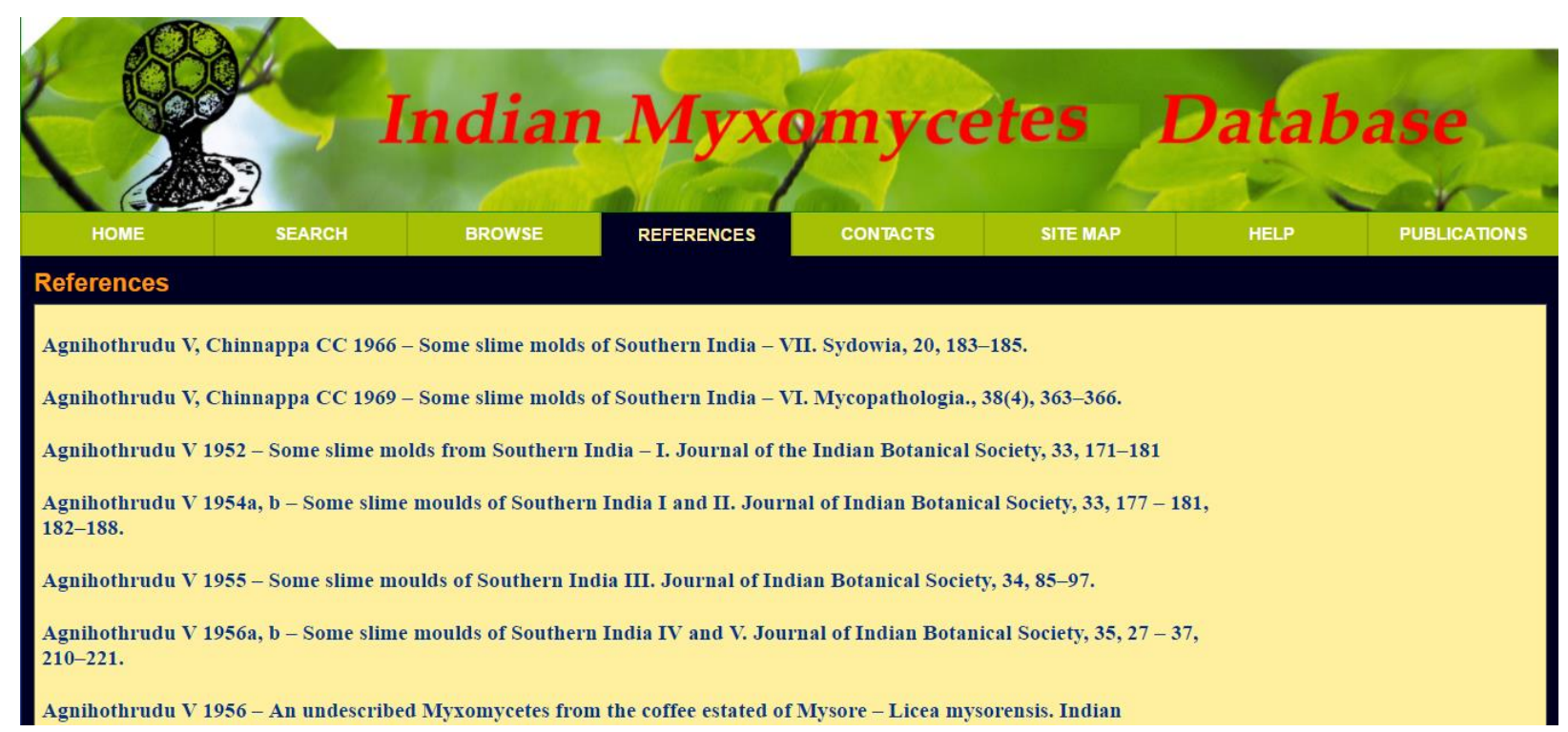

Fig. 8 - Database Reference page 


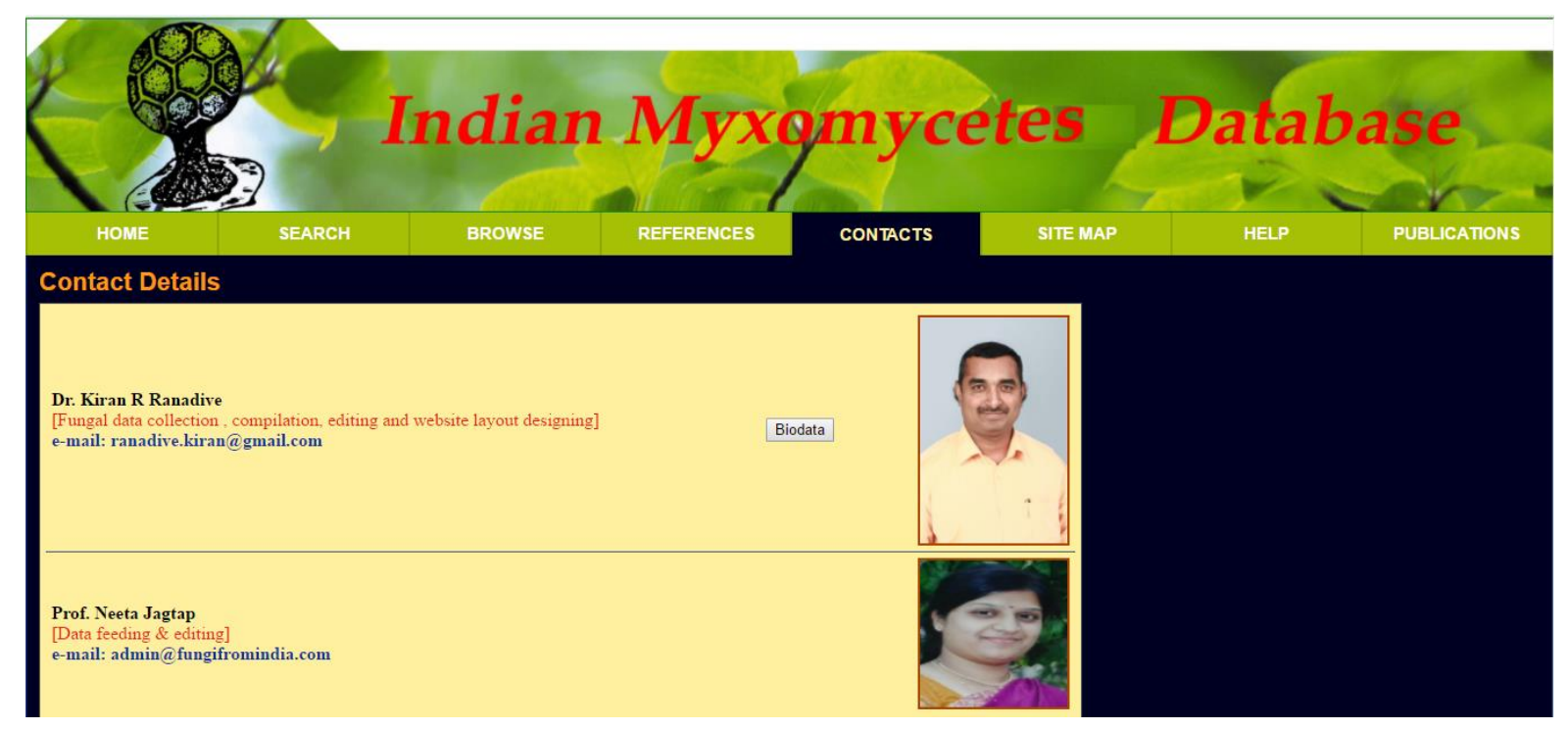

Fig. 9 - Database contact details page


Fig. 10 - Database Site map page

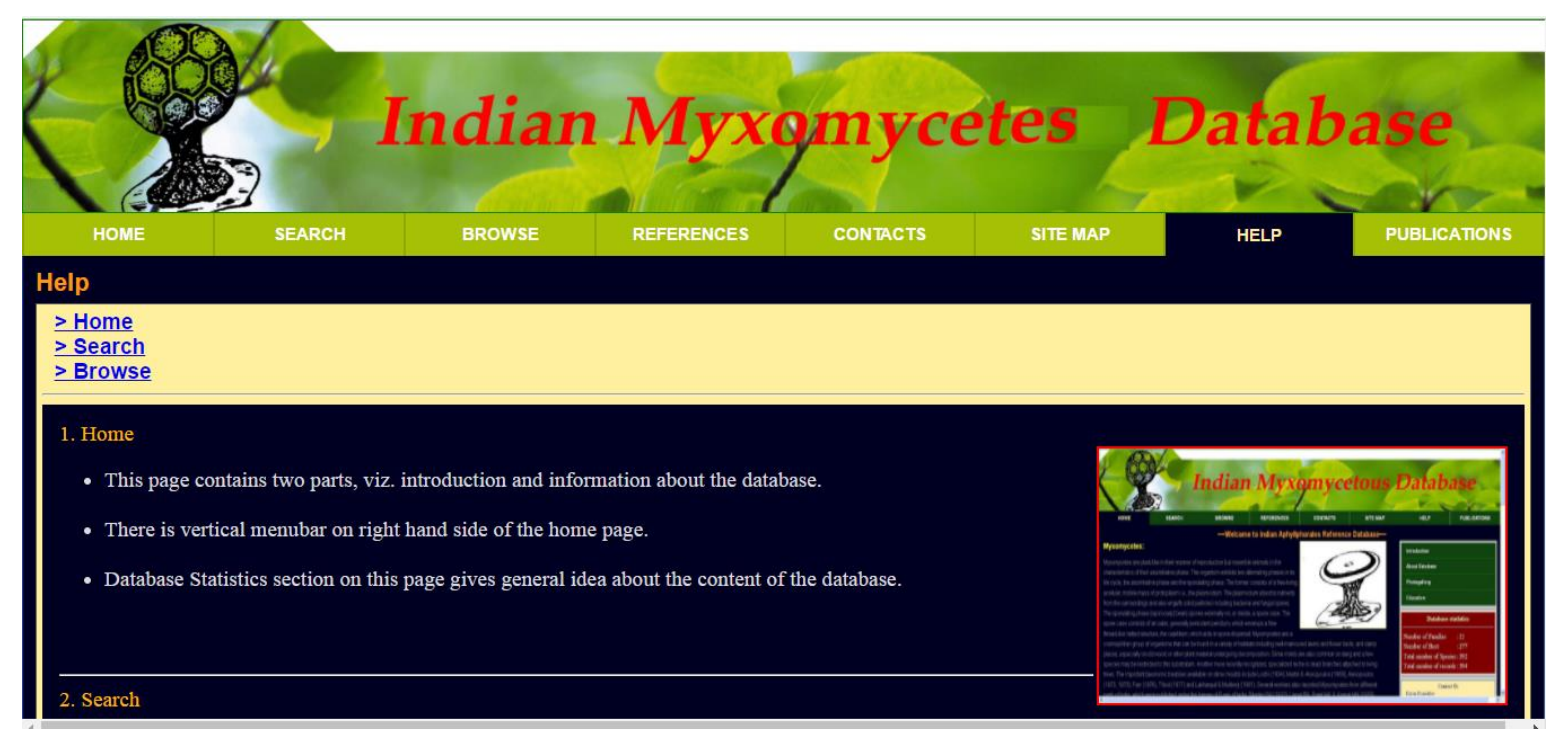

Fig. 11 - Database Help page 


\section{Acknowledgements}

It gives me great pleasure to avail this opportunity in acknowledging all those who were of immense help to me during the course of my research work. First and foremost, I express my deep sense of gratitude to Late Prof. J. G. Vaidya for suggesting the problem and providing constant guidance, cooperation and freedom during the entire period of my research work. I am grateful to our President of P.D.E.A.'s Hon. Ajit Pawar, Principal Dr. Nitin Ghorpade, Waghire college, Saswad, Tal- Purandar and all higher authorities of Poona District Education Association for encouragement. I am also very much thankful to other faculty members of Department of Botany, University of Pune for their direct as well as indirect encouragement. I can't forget the help and guidance extended by well-known Indian Mycologists Prof. T. N. Lakhanpal, regarding basic Myxomycetes taxonomy. I am highly indebted to my mother (Vimal) and father (Ramchandra) who steered the way through towards accomplishment of my goals, giving me a constant encouragement and by being besides me in every thick and thin, showing unfailing patience throughout the course of my work. I can't express my feelings in words about the help extended by Dr. Paul Kirk and Dr. Vincent Robert of www.mycobank.org for giving me free of cost linking to every species of this database and taxonomic literature help. I am especially grateful to Harshavardhan Khare and Mr. Nikhil Shivtare for their extreme help in database development, without whom the database would have had no existence. My sincere thanks are due to Mr. Rahul Kale (ARI Pune, Library) who helped me a lot during the survey of literature. I am unable to conclude the acknowledgment without expressing my special thanks to Ashish Deodhar and all family members for their constant support and encouragement.

\section{References}

Agnihothrudu V, Chinnappa CC. 1966 - Some slime molds of Southern India VII. Sydowia 20, $183-185$.

Agnihothrudu V, Chinnappa CC. 1969- Some slime molds of Southern India VI. Mycopathologia 38, 363-366.

Agnihothrudu V. 1952 - Some slime molds from Southern India I. Journal of the Indian Botanical Society 33, 171-181.

Agnihothrudu V. 1954a - Some slime moulds of Southern India I. Journal of Indian Botanical Society 33, 177-181.

Agnihothrudu V. 1954b - Some slime moulds of Southern India II. Journal of Indian Botanical Society 33, 182-188.

Agnihothrudu V. 1955 - Some slime moulds of Southern India III. Journal of Indian Botanical Society 34, 85-97.

Agnihothrudu V. 1956a - Some slime moulds of Southern India IV. Journal of Indian Botanical Society $35,27-37$.

Agnihothrudu V. 1956b - Some slime moulds of Southern India V. Journal of Indian Botanical Society 35, 210-221.

Agnihothrudu V. 1956c - An undescribed Myxomycetes from the coffee estated of Mysore - Licea mysorensis. Indian Phytopathology 18, 92-94.

Agnihothrudu V. 1958 - Notes on fungi from North East India II. An undescribed Myxomycetes from Assam. Journal of the Indian Botanical Society 37, 499-503.

Agnihothrudu V. 1959 - Notes of Fungi from North East India IV. Journal of Indian Botanical Society 38, 418-491.

Agnihothrudu V. 1961 - A List of Indian Myxomycetes. Journal of Madras University B, 1-20.

Agnihothrudu V. 1963 - Physarum laevisporum. Sydowia 16, 121.

Agnihothrudu V. 1968 - Some slime moulds of Southern India X. Sydowia 22, 179-182.

Ainsworth CG, Susman AF. 1973 - The Fungi "An advance treatise". IV-B., Academic press, London, pp. 504.

Alexopoulos CJ. 1963 - The Myxomycetes. Botanical Review 29, 1-78. 
Alexopoulos CJ. 1967 - Taxonomic studies in the Myxomycetes I. The genus Macbrideola. Mycologia 59, 103-116.

Alexopoulos CJ. 1969 - The experimental approach to the taxonomy of Myxomycetes. Mycologia 61, 219-239.

Alexopoulos CJ, Mims CW, Blackwell M. 1996 - Introductory Mycology, 4th Edition, John, Wiley $\&$ Sons. Inc. New York \& London, pp.869

Bhide VP, Pande A, Sathe AV, Rao VG, Patwardhan PG 1987 - Fungi of Maharashtra, (Supplement I), Maharashtra Association for the Cultivation of Science, Pune. pp.146.

Bilgrami KS, Jamaluddin S, Rizwi MA. 1979 - Fungi of India Part I, List and References. Today \& Tomorrow's Printers and Publishers, New Delhi, pp. 467.

Bruhl P, Gupta JS. 1927 - Indian Slime Fungi (Myxomycetes or Mycetozoa). First contribution. Journal Department of Science, University of Calcutta 8, 101-122.

Butler EJ, Bisby GR. 1931 - The Fungi of India. Imperial Council of Agriculture Research India, Science Monograph, 1. Calcutta, pp. 237.

Butler EJ, Bisby GR revised by Vasudeva RS. 1960 - The Fungi of India Indian Council of Agricultural Research New Delhi, pp. 552.

Chavan PD, Kulkarni UV. 1974 - Additions to the fungi from Maharashtra, India. Maharashtra Vidyan Mandir Patrika 9, 132-139

Dasgupta, K. 2005 - Digitization, sustainability and access in the Indian context. World Library and Information Congress: $71^{\text {th }}$ IFLA General Conference and Council, "Libraries- A voyage of discovery", pp. 12.

Dhillon SS. 1976 - Myxomycetes of North Western Himalayas. Ph. D. Thesis, Punjab University, Chandigarh.

Dhillon SS, Nannenga-Bremekamp NE. 1977 - Notes on some Myxomycetes from the north Western part of the Himalaya.Proc. of Koninkl. Nederl. Akad. van Wetenschappen. Ser. C 80, 257-266.

Dhillon SS, Nannenga-Bremekamp NE. 1978 - Notes on some Myxomycetes from North Western part of the Himalaya. Proc. of Koninkl. Nederl. Akad. van Wetenschappen. Ser. C 81, 141-149.

Dhillon SS. 1977a - Myxomycetes New to India I. Sydowia 30, 1-5.

Dhillon SS. 1977b - Myxomycetes New to India II. Sydowia 31, $27-29$.

Farr ML. 1962 - Arcyria cinerea \& Arcyria pomiformis, revised. Mycologia 54, 516-520.

Ghosh GR, Datta BG. 1962a - Myxomycetes from Orissa (India) I. Mycopathologia 16, 165-176.

Ghosh GR, Datta BG. 1962b - Myxomycetes from Orissa (India) II. Mycopathologia 16, 209-218.

Ghosh GR, Datta BG. 1962c - Myxomycetes from Orissa. Proceeding $49^{\text {th }}$ Indian Science Congress, Part III, pp. 243.

Ghosh GR, Datta BG. 1963 - Myxomycetes from Orissa (India) - III. Mycopathologia. 19, 271282.

Hosagoudar VB, Abraham TK, Pusphangadan P. 1996 - Fungi of Kerala. Tropical Botanic Garden and Research Institute 1-151.

Indira PU. 1968a - Some slime molds from Southern India - VIII. Journal of Indian Botanical Society 47, 155-186.

Indira PU. 1968b - Some slime molds from Southern India - IX. Distribution, habitat and Variation. Journal of Indian Botanical Society 47, 330-340.

Indira PU. 1975 - Some slime molds of Southern India - XI. Kavaka 3, 41-54.

Jagtap AP, Singh NP. 2002 - Biodiversity of the Western Ghats of Maharashtra - Current Knowledge. Published by Bishen Singh Mahendra Pal Singh, Dehradun, Appendix XXV, 339-342.

Jamaluddin S, Goswami MG, Ojha BM. 2004 - Fungi of India 1989 - 2001. Scientific Publishers (India), Jodhpur, 1-326. 
Kamat MN, Patwardhan PG, Rao VG, Sathe AV. 1971 - Fungi of Maharashtra, Bulletin No. 1. Maharashtra Association for Cultivation of Science, Poona \& Mahatma Phule Krishi Vidyapeth, Rahuri, Maharashtra, pp. 124.

Kar A. 1964 - Myxomycetes of Calcutta Suburbs. Indian Phytopathology 17, 222-223.

Kaur S, Mukherji KG. 1996 - Arcyria rufosa: A new Indian Myxomycetes. Mycotaxon 59, 479481.

Kowalski DT, Lakhanpal TN. 1973 - A new species of Didymium from India. Mycologia 65, 474477.

Lakhanpal TN. 1966 - Taxonomic studies on the Mxyomycetes of Simla and Kulu Hills (Himachal Pradesh). M. Sc. Thesis, Punjab University, Chandigarh.

Lakhanpal TN. 1978 - Taxonomic studies on the Indian Myxomycetes - XVIII. Two species of Myxomycetes and a reappraisal of the genus Lepidodermopsis. Norwegian Journal of Botany 25, 196.

Lakhanpal, T.N. 1971 - Myxomycetes of Himachal Pradesh - I. Sydowia 25, 232-239.

Lakhanpal, T.N. 1972 a - Myxomycetes of Delhi. Sydowia 26, 210-213.

Lakhanpal, T.N. 1972 b - Myxomycetes of Nainital. Sydowia 26, 214-216.

Lakhanpal, T.N. 1973 - Myxomycetes of Himachal Pradesh - II. Ind. Phytopath 26, 691-697.

Lakhanpal TN, Mukherji KG. 1981 - Taxonomy of the Indian Myxomycetes. J. Cramer, FL - 9490 VADUZ, pp. 411.

Lister G. 1924 - Mycetozoa from North India. Journal of Botany 62, 16-20.

Lister G. 1925 - A monograph of Mycetozoa. 03 ${ }^{\text {rd }}$ Edition, British Museum (Nat. Hist.) London, pp. 296.

Lodhi SA. 1934 - Indian slime moulds (Myxomycetes) Research Publications University of Punjab $5,1-34$

Martin GW. 1932 - Systematic Position of Myxomycetes and its bearing on Classification of Fungi. Botanical Gazzette 93, 421-435.

Martin GW, Thind KS, Sohi HS. 1957 - The Myxomycetes of Mussorie Hills - IV. Mycologia 49, 128-133.

Martin GW, Alexopoulos CJ. 1969 - The Myxomycetes. University of Iowa Press, Iowa, pp 560.

Mathur RS. 1964 - Myxomycetes of India. Labdev. Jour. Sci. \& Tech. Kanpur. (India). 2, 164-174.

Mishra RL, Ranade VD. 1979 - Mxyomycetes of Maharashtra - II. The genus Diderma. Maharashtra Vidnyan Mandir Patrika 14, 33-41.

Mukherji KG, Juneja RC. 1975 - Fungi of India Supplement to the list of Fungi (1962-1972). Emkay Publications Delhi, 1-250.

Mueller GM, Bills GF, Foster MS. 2004 - Biodiversity of Fungi Inventory and Monitoring methods. Elsevier Academic press, pp. 777.

Mundkur BB. 1938 - Fungi of India. Supplement - I. The Imperial Council of Agricultural Research. Science Monograph 12, 1-54.

Nagarkar S. 2000 - Pune-Net: Current Status. Information Today and Tomorrow 19, 16-18.

Nanir SP. 1979 - Myxomycetes of Marathwada. Ph.D thesis, Marathwada University. Nanir SP 1985 - Contribution to the knowledge of Myxomycetes from India - III B. Indian Botanical Reporter - IV, 42-45

Nanir SP, Rokade BG. 1987 - Myxomycetes of Marathwada - I. Marathwada University Journal of Science 12.

Nanir SP, Rokade BG, 1993 - Myxomycetes of Jalgaon and Dhule District (Khandesh): India. Abstract National Conference on Recent Advances in Pathology, 14.

Nannega-Bremekamp NE. 1958a - Notes on Myxomycetes. I. Some remarks on the genus Reticularia. Bull. Emend. Rost. Med. Bot. Mus. Herb. Utrecht 149, 769-779.

Nannega-Bremekamp NE. 1958b - Notes on Myxomycetes. II. Med. Bot. Mus. Herb. Utrecht 150, 780-785.

Nannega-Bremekamp NE. 1967 - Notes on Myxomycetes. XII. A revision of Stemonitales. Proc Kon Ned Akad Wetensch C 70, 201-216. 
Palm ME, Chapela IH. 1997 - Mycology in Sustainable Development: Expanding concepts, vanishing borders. Parkway, Boone, North Carolina, pp 306.

Pathak NC, Ghosh RN. 1962 - Fungi of Uttar Pradesh. Bulletin of the National Botanical Gardens, National Botanic Gardens, Lucknow, India. No, 62.

Patel MK, Kamat MN, Bhide VP. 1948 - The Fungi of Bombay Supplement I. Indian Phytopath 2, $142-155$

Patil SD, Mishra RL. 1977 - An atypical form of Physarum pusillum. Maharashtra Vidnyan Mandir Patrika 12, 41-42.

Patil SD, Ranade VD. 1975 - Myxomycetes of Maharashtra - I. The genus Diderma. Pers. Indian Science Congress (Abstracts). 62nd Session.

Patwardhan PG, Joshi GT. 1975 - Myxomycetes of Maharashtra, India. Part - I. Bio - Vigyanam, $1,49-53$.

Ramakrishnan K, Subramanian CV. 1952 - The Fungi of India - A Second Supplement. Journal of Madras University, B. XII, pp.65.

Ranade VD, Mishra RL. 1977 - Myxomycetes of Maharashtra - III. Maharashtra Vidnyan Mandir Patrika 12, 25-27.

Ranade VD. 1978 - Myxomycetes of Maharashtra, Ph. D Thesis, University of Pune 1-226.

Ranade VD, Korade ST, Jagtap AV, Ranadive KR. 2012 - Checklist of Myxomycetes from India Mycosphere 3, 358-390.

Rangaswamy G, Sheshadri VS, Lucy Channama KA. 1970 - Fungi of South India.W.Q. Judge press, (Division of international Book House Pvt. Ltd., Bombay), Banglore, India, 30.

Roy TC, 1948 - Fungi of Bengal. Bull. Bot. Soc, Bengal 2, 134-177.

Sarbhoy AK, Lal G, Varshney JL. 1975 - Fungi of India (revised) 1967-1971. Navyug Traders Bookseller \& Publishers, New Delhi. pp. 148.

Sarabhoy AK, Agarwal DK, Varshney JL. 1980 - Fungi of India (1971-1976). Navyug Traders Booksellers \& Publishers, New Delhi, pp. 277.

Sarabhoy AK, Agarwal DK, Varshney JL. 1986 - Fungi of India (1977-1981). Associated Publishing Company, New Delhi, pp. 274.

Sekhon SS. 1976 - The genus Licea Schrad. in India. Proc. $63^{\text {rd }}$ Indian Science Conference. Part III, 60.

Sekhon SS. 1978 - The Myxomycetes of Chandigarh - I. Journal of Indian Botanical Society 57, 331-337.

Sekhon SS. 1979a - The Myxomycetes of Chandigarh - II. Journal of Indian Botanical Society 58, $16-20$.

Sekhon SS. 1979b - The genus Badhamia Berk. in India. Journal of Indian Botanical Society 58, 56-83.

Singh HH, Pushpavathy KK. 1965 - The Slime Molds of Delhi - I Mycopathologia 27, 23-40.

Singh HH, Pushpavathy KK. 1966 - The Slime Molds of Delhi - II Mycopathologia 28, 265-272.

Singh HH, Pushpavathy KK, Sethi I. 1979 - The Slime Molds of Delhi - III. Proceeding of Indian National Science Academy 45, 375-382.

Sood R, Lakhanpal TN. 1980 - Taxonomic studies of Indian Myxomycetes - XIX. Sydowia XXXIII, 174-180.

Subramaniam CV, Ramakrishnan K. 1956 - List of Indian Fungi (1952-1956). Journal of Madras University B 26, 327-421.

Subramaniam CV, Tyagi PD. 1964 - List of Indian Fungi (1956-1960). Journal Madras University 34, pp.134.

Tandon RN, Chandra S. 1964 - Supplement to the list of Indian Fungi (1957-1962). University of Allahabad studies (Botany Publication); PUBL University Allahabad, Allahabad.

Tembhurne RR, Nanir SP. 2011 - The Myxomycetes of South - West Maharashtra (India) - III. Plant Science Feed 1, 23-27.

Tembhurne RR, Nanir SP. 2011 - New five species of the Myxomycetes recorded from the South East Region of Maharashtra (India). Science Reporter 1, 65-68. 
Thind KS, Rehill PS. 1957 - The Myxomycetes of the Mussoorie Hills - VII. Indian Phytopathology 10, 85-96.

Thind KS, Sehgal HS. 1960 - The Myxomycetes of India - XIII. Indian Phytopathology 13, 103117.

Thind KS, Manocha MS. 1963 - The Mxyomycetes of India - XV. Indian Phytopathology 16, 177-184.

Thind KS, Sehgal HS. 1964 - The Myxomycetes of India - XVI. Mycologia 56, 561-567.

Thind KS, Khara HS. 1969 - The Myxomycetes of India - XXIII. Proceedings of Indian Academy of Science 69, 284-293

Thind KS, Lakhanpal TN. 1968 a - The Myxomycetes of India - XIX. Indian Phytopathology 21: 92-102.

Thind, KS, Lakhanpal TN. 1968b - The Myxomycetes of India - XX. Indian Phytopathology 21, 198-208.

Thind KS, Lakhanpal TN. 1968c - The Myxomycetes of India - XXI. Indian Phytopathology 21, 223-231.

Thind KS. 1977 - The Myxomycetes of India. Indian Council of Agricultural Research, New Delhi, pp. 452.

Thite AN, 1975 - New and Noteworthy Fungi from Maharashtra. Maharashtra Vidnyan Mandir Patrika 9, 117-120.

Tilak ST, Rao R. 1968 - Second Supplement to the Fungi of India (1962-1967), Marathwada University, Marathwada, pp.312.

Uppal BN, Patel MK, Kamat MN. 1935 - The Fungi of Bombay, Bulletin number 176 of 1934, Department of Agriculture, Bombay. Printed at the Government Central Press, VIII, pp. 56.

Vasudeva RS. 1962 - Fungi of India Supplement I. Indian Council of Agricultural Research, New Delhi, pp. 206.

Wrigley D, Lado C. 2005 - A taxonomic evaluation of the stipitate Licea species. Fungal Diversity 20, 261-314

www.fungifromindia.com/fungiFromIndia/buildPage.php?page=databases

www.indexfungorum.org/names/names.asp

www.mycobank.org/ 